\title{
Ikke en solskinnshistorie
}

\author{
Jeg er 33 år gammel. I mange \\ av disse årene ventet jeg på at \\ noen jeg var glad i skulle bli \\ friskmeldt fra noe jeg ennå ikke \\ forstår hva var.
}

Som pårørende har det vært frustrerende å forholde seg til det uforståelige at mennesker som på utsiden har alle forutsetninger for å være lykkelige, allikevel ikke har det bra. Det irrasjonelle ved lidelsens natur gir ventetiden et nærmest evig perspektiv.

Psykiske lidelser blir ofte omtalt som folkesykdommer som kan helbredes ved hjelp av lavterskeltilbud i psykiatrien. Det skal bli enklere å få hjelp når du er syk, slik at du kan bli helt frisk og til slutt komme tilbake på jobb.

Det er snart fem år siden broren min tok sitt liv. Jeg er helt sikker på at jeg kan takke psykiateren hans for at han ikke døde tidligere. Det at han ble tatt på alvor, forlenget livet hans. Han døde ikke på grunn av, men på tross av langvaring behandling. Den respekten han ble møtt med, håper jeg blir alle til del. Selv om løsningene ofte ligger langt frem i tid.

Jeg er redd det er en vedvarende undervurdering av problemene i den psykiske helsekøen. Misforstå meg rett: Alle som er syke, må få hjelp. Mange store problemer kunne forblitt små om de fikk oppmerksomheten de fortjente. Men først og fremst må de aller sykeste få komme fremst i køen. Hverdagslivets opp- og nedturer rammer alle mennesker. En klok, raus og erfaren fastlege kan håndtere mye av dette.
Mitt inntrykk er at noen politikere vil opprette en psykologbemannet særomsorg for folk som er lei seg. Det kan i verste fall føre til sykeliggjøring av normale reaksjoner. Jeg savner forståelsen av hva kronisk sykdom er. For mange av dem som får døgnbehandling i psykisk helsevern for voksne, er det ikke nok med ett opphold. I 2009 hadde om lag $40 \%$ av døgnpasientene flere institusjonsopphold. Det er dessverre slik at psykisk sykdom ofte er en livslang kamp. Det er dette vi må ta på alvor.

I den kampen må vi ikke undervurdere kompetanse. Det er ekstremt viktig å ha et tilstedeværende tilbud alle dager. Og trusselen om å ta sitt liv må ikke være inngangsbilletten. Kampen om å holde folk i live over tid kan være seig og langsom. Behandlingen er ofte livslang, og den skal skje i spesialisthelsetjenesten eller i samarbeid med denne. Slik behandling krever ofte miljøer med spisskompetanse, derfor kan desentralisering være skadelig. Beklageligvis er ventetiden for utredning og behandling ofte altfor lang.

Mesteparten av tiden er pasientene utenfor institusjon. Av og til er imidlertid innleggelse nødvendig - en timeout. Dessverre er et slikt tilbud ofte ikke tilgjengelig. Målet må være at innleggelsen har så stor verdi at pasienten ikke reinnlegges etter kort tid.

Andre har lidelser som skal utredes i spesialisthelsetjenesten, men som stort sett kan håndteres i primærhelsetjenesten. Samarbeid og god kommunikasjon mellom primær- og spesialisthelsetjenesten er viktig. Ved første gangs henvisning er det ofte «krise». «Fort inn og fort ut» kan være en passende betegnelse på spesialisthelsetjenestens håndtering av disse tilfellene.
Mesteparten av tiden skal pasientene tas hånd om av fastlegene, eventuelt av den kommunale psykiatritjenesten.

Til slutt vil jeg slå et slag for de utrydningstruede avtalespesialistene - psykologspesialister og spesialister i psykiatri som har avtale med staten og som mottar pasienter på samme økonomiske vilkår som en psykiatrisk poliklinikk. Hos disse møter pasienten én behandler over lengre tid, selv om det i de store byene ofte er flere samlokalisert. Mange av dem gjør en fantastisk jobb. Jeg er usikker på helseforetakenes holdninger til avtalespesialistene, det kan ser ut som om foretakene heller vil bruke pengene på egne poliklinikker. En videreutvikling av disse tjenestene kan utfylle poliklinikkenes på en utmerket måte.

Den psykiske helsekøen er dessverre lengre enn billettkøen til Justin Bieber. Mennesker med psykiske helseproblemer som trenger hjelp kan fylle Spektrum både én og to ganger. Alle disse burde ha rett til en solid faglig vurdering etter kort ventetid og deretter langvarig behandling om nødvendig. Dette svikter stort i dag. Bedring på dette feltet tror jeg vil medføre bedre ressursbruk. Og - ikke minst - flere overlevende med et verdig liv.

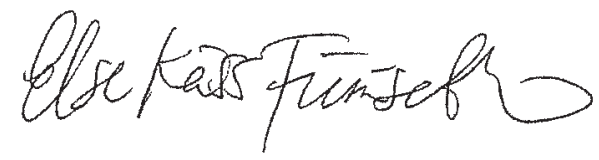

